\title{
MAKUNAIMA E MACUNAÍMA: DOIS TRICKSTERS
}

\author{
Renato Amado Barreto ${ }^{102}$ \\ Ana Lúcia Machado de Oliveira ${ }^{103}$
}

RESUMO: Macunaíma, protagonista da obra clássica de Mário de Andrade, foi inspirado no herói mitológico dos povos pemons, da região do circun-Roraima, Makunaima, um ser transnacional que existe em comunidades indígenas de três países sul-americanos: Brasil, Venezuela e Guiana. Veremos que os dois personagens são tricksters, e por isso têm diversos aspectos em comum. O trickster é um conceito extraído da observação de personagens mitológicos de culturas distintas, mas que conjugam certas características, dentre as quais se destacam a astúcia e o poder de mediação. Desse modo, primeiro discutiremos alguns aspectos essenciais dos tricksters. Ao final da primeira seção resumiremos, em tópicos, estes aspectos. Na segunda seção verificaremos, um a um, como eles se manifestam nos personagens em análise e em quais pontos percebemos interseções e afastamentos entre eles.

Palavras-chave: Macunaíma. Makunaima. Trickster. Mitologia.

ABSTRACT: Macunaíma, protagonist of the classic Mário de Andrade `s novel, had its creation inspired by the mythological hero of the Pemon people, from the area around Mount Roraima, Makunaima, a transnational being that exists in indigenous communities in three South American countries: Brazil, Venezuela and Guyana. It will be shown, in this article, that the two characters are tricksters, and so they have many aspects in common. The trickster is a concept extracted from the observation of mythological characters from different cultures, but which combine certain characteristics, among which stand out the cunning and the power of mediation. Thus, first this article will address some essential aspects of the tricksters. At the end of the first session, these aspects will be summarized in topics. In the second session it will be made a check list, verifying if and how these features manifest themselves in the characters in question and on which points we may notice intersections and distances between them.

\footnotetext{
102 Doutorando em Estudos Portugueses e Brasileiros, ênfase em literatura, pela Brown University, Providence, EUA.

${ }^{103}$ Doutora em Literatura Brasileira pela Universidade do Estado do Rio de Janeiro - UERJ -

e Professora Associada do Departamento de Letras da mesma universidade.
} 
Keywords: Macunaíma. Makunaima. Trickster. Mythology.

\section{INTRODUÇÃO}

Makunaima é o trickster dos povos pemons, que vivem na região do circun-Roraima. Embora compartilhem idioma, há diversas nações entre os pemons, quais sejam, os arekuna, taurepang, kamarakoto e macuxi (CARVALHO \& JOBIM, 2009, p. 30). Estes povos ocupam partes de três países: Brasil, Venezuela e Guiana. Makunaima, portanto, é um personagem transnacional, tanto em termos de fronteiras de Estados modernos, quanto de nações indígenas. A despeito de sua importância numa região de considerável extensão geográfica, manteve-se inaudito à sociedade ocidental até o livro de Koch-Grünberg, Vom Roraima zum Orinoco - publicado originalmente em alemão, em 1917, em cinco volumes -, tendo sido popularizado pela obra de Mário de Andrade, Macunaíma, um herói sem nenhum caráter, que se inspirou no trabalho do pesquisador alemão. Sem dúvida, o recente boom turístico pelo qual passa o Monte Roraima, com diversas excursões diárias, amplia ainda mais a fama deste herói que, assim como o da literatura, é sem nenhum caráter.

Vale comentar que Makunaima, nas últimas décadas, passou por uma metamorfose. Hoje é conhecido pelos jovens índios pemons como um herói sem ambiguidade, ao contrário do que costumava ser, como trickster que é, como se verá no decorrer deste estudo. Ele cumpre uma função moralizadora, ao mesmo tempo em que atende à demanda por resgate dos valores autóctones (cf. CARVALHO \& JOBIM, 2009, p. 27) ou, ao menos, dá a impressão de atender. Atualmente, a maioria das comunidades pemons é parte das culturas venezuelana ou brasileira. Além de dominar o idioma do país em que se insere, a maioria destes índios se declara como adventistas ${ }^{104}$, embora eles ainda acreditem em algumas lendas e mitos pemons. Conforme parece evidente, se alguém é cristão, não pode ter um trickster como herói, por uma incompatibilidade de valores. Então, a forma de enaltecer a cultura local é resgatar o herói, mas com outra face, numa espécie de antropofagia invertida. A esse respeito, cabe citar a seguinte observação de Carvalho e Jobim:

${ }^{104}$ Como pudemos verificar pessoalmente, em visita ao Monte Roraima. 
Como personagem que se presta a uma finalidade moralista e, por conseguinte, formadora das novas gerações de índios Pemon; com circulação pretendida como leitura literária, mas também paradidática, a ser empregada, de forma particular, no âmbito da escola e nas esferas de formação da juventude indígena (CARVALHO \& JOBIM, 2009, p. 27).

É o Makunaima com que o etnógrafo alemão teve contato, contudo, que nos interessa, uma vez que neste trabalho pretendemos demonstrar que ele e o protagonista marioandradiano pertencem à mesma classe de seres, qual seja, a dos tricksters. Na próxima seção, apresentaremos os aspectos essenciais deste conceito. Verificaremos em que extensão tais aspectos se aplicam aos personagens em análise, sendo assim possível demonstrar suas principais semelhanças e diferenças e, sobretudo, que ambos são tricksters, residindo aí o principal motivo de o escritor modernista ter aproveitado o nome do demiurgo mitológico, com apenas uma diferença de grafia.

Acerca da grafia do nome do herói pemon, registre-se que o antropólogo alemão e a autora Silvia M.S. de Carvalho, que serão citados neste artigo, escrevem "Makunaíma", contudo, na visita que fizemos ao Monte Roraima tivemos a oportunidade de conversar com índios de Parateipuy - comunidade arekuna localizada próxima à base do Monte - e com guias que foram enfáticos em afirmar que a letra tônica da palavra é o segundo "a". Como afirmam Fábio Almeida de Carvalho e José Luis Jobim, “'Makunaima' é a designação corrente entre os índios Pemon e os regionais de Roraima" (CARVALHO \& JOBIM, 2009, p. 13). Deste modo, optamos, neste estudo, pela grafia sem o acento agudo, preservando, contudo, a redação dos autores em citações.

\section{O TRICKSTER: ASPECTOS GERAIS}

Em linhas gerais, o trickster é um frequente arquétipo mitológico, encontrado em diversas culturas, que surge como um mediador, para resolver contradições. Considerando-se que as atividades humanas encontram pontos de contradições, a função central do mito, segundo LéviStrauss, seria a de buscar superá-las (LÉVI-STRAUSS, 2012, p. 325-329). Mas, como são insuperáveis, criam-se constantemente novos mitos sobre as mesmas temáticas. Uma vez que uma contradição se constitui de uma oposição entre distintas ações, um ser arquetípico que represente 
simultaneamente estas duas ações pode ser uma forma mais ou menos eficaz de tentar equacioná-la.

Esse duplo caráter do trickster faz com que ele pertença a dois ou mais mundos e ao mesmo tempo a nenhum deles. Ele tem, portanto, autonomia em relação aos universos dos quais faz parte, sendo capaz de, frequentemente, colocar em xeque os valores destes universos. Se o trickster, ao mesmo tempo em que representa um determinado mundo ou prática, representa outro(a) que a ele(a) se opõe, ele será um ser dúbio, simultaneamente aliado e inimigo.

Silvia M. S. de Carvalho, no artigo "O trickster como personificação de uma práxis” (1985), clareia a questão, ao tratar daqueles tricksters que buscam superar as contradições do delicado equilíbrio das sociedades humanas com a natureza, à qual ela se refere como "outro". É que o ser humano necessita extrair elementos da natureza - o que ela chama de "punção" - para sua subsistência. Contudo, caso os extraia em demasia, os recursos disponiveis se esgotam. Desse modo, é frequente haver tricksters que simultaneamente incentivam e limitam a punção da natureza. Assim, eles estarão ao lado do ser humano, fornecendo tecnologias, como o anzol, para aprimorar a punção; outras vezes, contudo, estarão ao lado da natureza, castigando o ser humano por alguma ação indevida ou simplesmente ajudando elementos da natureza contra o ser humano.

Como faz a ligação entre mundos, é comum que o trickster seja um mensageiro, como Exu (trickster ioruba, trazido ao Brasil pelos escravos) e Hermes (trickster da Grécia clássica). Mesmo alguns que não são definidos como tais são associados ao deslocamento ou se deslocam muito nas suas histórias ou mitologias. O trickster é um ser ligado aos caminhos, capaz de abri-los e fechá-los, pois, por pertencer a mais de um mundo, aponta diferentes possibilidades de rotas, dentre as quais se incluem as que transgridem e as que se mantêm de acordo com a ordem vigente, pois, como um ser ambíguo, ele é simultaneamente um transgressor e um garantidor da ordem; não à toa, em muitas mitologias, é considerado um guardião. Se Exu é um grande transgressor, ao mesmo tempo pune quem deixa de cumprir mandamentos divinos, sobretudo de Olorum, o deus supremo. Já Hermes cumpre fielmente diversas ordens de Zeus.

É relevante ainda destacar que algo reincidente entre os tricksters é o fato de seguirem ciclos. No início, são tomados pela inconsciência e guiados por luxúria e fome incontroláveis. São escravos, neste momento, do que Freud definiu como "princípio do prazer", que se refere ao propósito dominante da atividade psíquica, sobretudo em seu nascedouro: 
evitar o desprazer e buscar o prazer (FREUD, s/d, p. 1), por meio do atendimento às excitações que chegam através dos sentidos, sem considerações de outras ordens, sejam estratégicas (se todo o alimento que naquele momento é desejado for consumido, haverá escassez adiante) ou morais. Suas ações desmedidas, em busca de satisfazer tais apetites, geram consequências terriveis para eles - e, muitas vezes, para a humanidade, criando tabus, uma vez que, ao menos os trickster mitológicos, costumam ser seres primordiais -, que só vêm a atingir o equilibrio quando passam a conter seus desejos.

No primeiro momento do ciclo, alguns tricksters mal têm consciência sobre o próprio corpo. Em uma história do trickster Wakdjunkaga, do povo winnebago, da América do Norte, suas mãos esquerda e direita disputam por alimento e então uma fere a outra. Apenas ao sentir a dor, Wakdjunkaga percebe que brigava contra si mesmo (RADIN, 1956, p. 8).

Tricksters que seguem este ciclo estão, em um primeiro momento, aquém dos animais, pois estes possuem habilidades inatas, algo que falece aos tricksters. Contudo, estes detêm inteligência e, observando as ações dos animais, passam a copiá-las com as adaptações necessárias, em momentos oportunos. Assim, superam os animais, pois têm à disposição diversas técnicas usadas por diferentes espécies. Tornam-se, assim, astutos, mestres da trapaça, da malandragem, sendo mutantes e adaptáveis.

Nesse processo de aprendizagem, precisam aprender a controlar suas pulsões por alimento e sexo. É comum haver, nos ciclos tricksters, a seguinte oposição: ou contenção e obtenção prolongada de alimentos ou falta de contenção e abundância limitada no tempo. Isso tem uma finalidade educativa, uma vez que, se não houver uma contenção da demanda por alimentos, ocorrerá uma punção exagerada da natureza, esgotando os recursos disponíveis. Por isso encontramos várias histórias em que há recursos infinitos, mas, em função de uma falta de contenção do desejo alimentar do trickster, a comida passa a ser restrita.

Desse modo, em seu ciclo, o trickster acaba por aprender que deve haver uma contenção dos seus desejos. Essa suspensão da busca imediata por prazer foi denominada por Freud de "princípio da realidade". Tal aprendizagem, muitas vezes, é simbolizada pela redução de algum órgão ligado à digestão ou à sexualidade.

Quando o trickster amadurece e aprende a controlar suas pulsões, em um mundo agora com quantidade limitada de alimentos, desenvolve tecnologias e promove alterações no mundo que permitem o florescimento 
da cultura humana. Trata-se do trickster transformer, que corresponde ao lado herói-civilizador que muitos tricksters apresentam.

Ressalte-se, por fim, que a astúcia do trickster encontra no terreno da troca um campo favorável. Exu é o deus do mercado, do comércio. Como se sabe, a linguagem também é um ambiente de troca e convidativo à astúcia. Obtêm-se grandes vantagens através de um uso astucioso do verbo. Além disso, entre emissor e receptor há um espaço vazio que abre campo para a hermenêutica, para o desvio de linguagem, o mal entendido. Onde há espaço vazio há um mediador, há um trickster. Segundo Subirats: "El trickster es también un mediador de la unidad arcaica de la palabra y el ser (...). Provoca la risa" (SUBIRATS, 2014, p. 281). Ele é um bufão, que faz um uso esquivo e por vezes cômico da linguagem. Por isso muitos tricksters são deuses ligados à comunicação, como Exu e Hermes. A brincadeira, o jeito bufão, é uma forma de "puxar o tapete", criticar, passar uma rasteira até em quem está do seu lado, e é isso que o trickster faz. De dois mundos simultaneamente, constitui uma espécie de estranho aliado, um aliado pronto a criticá-lo, a criar dúvidas e problemas através de seu jeito ambíguo, a agir de forma que pareça uma traição.

Pelo exposto até aqui, em resumo, podemos dizer que as seguintes características são comuns aos tircksters:

a) é um mediador que transita entre diferentes mundos, buscando resolver contradições;

b) tabus são criados a partir de ações por ele tomadas;

c) quando é herói-civilizador, configura elemento fundamental no estabelecimento dos contornos que o mundo tem, com suas ações gerando produtos (como alimentos e tecnologias) que aproveitam ao ser humano ou interferem diretamente na sua vida;

d) é ligado ao deslocamento;

e) caminha pelo mundo primeiramente num estado quase inconsciente e, através da contenção de seus desejos, desenvolve uma inteligência astuciosa, através da qual obtém seus objetivos de forma aética e desprendida da ordem do cosmo em que se encontra, frequentemente fazendo uso esquivo da linguagem e de um estilo bufão. Não tem um caráter definido. É mutante, com grande capacidade de adaptação.

Demonstraremos, a seguir, que Makunaima e Macunaíma compartilham, em diferentes graus e formas, de tais características, sendo, portanto, ambos tricksters. 


\section{MACUNAÍMA E MAKUNAIMA, DOIS TRICKSTERS} 2.1 SÃO MEDIADORES ENTRE DIFERENTES MUNDOS?

\subsection{1 - Macunaíma}

Macunaíma é, por um lado, um mediador entre dois mundos: o do homem e o da natureza. E também entre três mundos: o das três principais etnias fundadoras da cultura brasileira. Desdobremos esses pontos em nossa análise.

O protagonista andradiano é um índio, portanto vive em espécie de simbiose com a natureza. O silvícola vê a natureza como fonte de subsistência e simultaneamente como ameaça. Para estabelecer-se como sedentário, precisa realizar uma punção controlada dos subsídios dados por ela. Mas Macunaíma se transforma em formiga quenquém; em caxipara, que é macho da formiga saúva; em aimará (espécie de peixe); em piranha feroz. Nota-se que, em geral, o herói se metamorfoseia em algum ser da natureza para fazer oposição ao humano e, muitas vezes, vira animais nocivos. Transforma-se em formiga quenquém para morder Iriqui; em caxipara para espiar se o gigante Piaimã terá medo de Chuvisco. Ele também vira aimará, uma espécie de peixe, para enganar um pescador e roubar seu anzol. Sua estratégia não funciona, então transforma-se em piranha para fazê-lo, engolindo e subtraindo o anzol do pescador. É curioso notar que, nesse ponto, Macunaíma vira um ser da natureza, se voltando contra um homem, para obter acesso a uma tecnologia que aprimorará o processo de punção da natureza. Este trecho deixa claro o caráter mediador e ambíguo do herói, que não se identifica nem com o lado "homem" nem com o lado "outro" - como Silvia M.S. de Carvalho (1985, p. 180) se refere à natureza -, agindo ora como de um lado ora como de outro, ao seu bel prazer, levado pelo seu desejo momentâneo. Também se transforma em pragas, como a lagarta rosada do algodão e a broca do café. Vira São Paulo num bicho preguiça todo de pedra, agressiva ação contra o ser humano. Contudo, transmuta seus irmãos em máquina-telefone diversas vezes, numa adesão à tecnologia.

Quando é morto por uma flechada de Piaimã é ressuscitado por uma formiga, lado outro, e pelo seu irmão, um humano, contando, ainda, com a ajuda de um carrapato. É ajudado por dois animais nocivos, portanto.

É inegável que o "herói de nossa gente" é, também, um trickster cultural, transitando entre as principais etnias do país. Trata-se de um índio que nasce preto retinto e torna-se branco. Estas transformações físicas talvez 
sejam uma sintética representação da essência do livro, que é a atuação de Macunaíma entre culturas, ora se aproximando, ora estressando sua relação com uma ou outra.

Segundo Gilda de Mello e Souza, a rapsódia marioandradiana traz dois sintagmas essenciais: a disputa de Macunaíma com Piaimã pela muiraquitã e seu antagonismo com Vei, a Sol. Há que se examinar o que representa cada um desses embates e sua relevância para o presente estudo. De acordo com a autora: "o primeiro sintagma, relacionado à vitória de Macunaíma contra Piaimã, se refere aos valores primitivos, simbolizados pelo Uraricoera; e o segundo, que descreve a derrota de Macunaíma diante de Vei, representa a atração perigosa da Europa, expressa na união com a portuguesa" (SOUZA, 2003, p. 51).

Temos, portanto, o herói representando papéis opostos nestes dois conflitos. No seu embate com Piaimã, Macunaíma acentua, sobretudo, seu lado índio, primitivo, enquanto Venceslau Pietro Petra é, para Cavalcanti Proença (apud CAMPOS, s/d, p.150), o estrangeiro. Segundo Haroldo de Campos:

O conflito, num primeiro nível, pode assim reduzir-se à confrontação de duas lideranças: a do solo (Macunaíma, lembremos, é o "Imperador do Mato Virgem") arraigada na terra, nacional por direito hereditário, e a alienígena, arrivista, promovida pela especulação financeira e pela emergência de uma economia de consumo acoroçoada via industrialização.

(...)

A oposição mais nítida que se poderia estabelecer entre o "herói sem nenhum caráter" e o façanhudo antagonista "mau caráter" é, talvez, para além do conflito "nacional" /"estrangeiro", a que se põe entre o anárquico e o estabilizado, entre um polo de desorganização criativa e seminal, ainda quando perversa, e outro de poderio concentrado e satisfeito, refestelado e repressivo, embora grotescamente caricaturado (CAMPOS, s/d, p. 151-152).

Verifica-se, portanto, um conflito de valores ligados à etnia que representa cada um dos contendores. Venceslau Pietro Petra encarna o estrangeiro e os valores ligados à economia e à cultura branca, como a acumulação do capital, a ordem, a contenção. Já Macunaima, neste 
sintagma, agiria como representante dos valores autóctones e do caos criativo que a tais valores (equivocadamente ou não) comumente é atribuído.

Contraditório como um trickster, Macunaíma, representante dos valores primitivos no embate com Piaimã, coleciona palavras estrangeiras, transforma os irmãos em telefone, volta ao Uraricoera carregado de bens da metrópole, como revólveres e relógio, que usa como enfeites e brincos, alterando seu uso normal e dando-lhes uma atribuição mais ligada à prática indígena. Como se não bastasse, o herói trai o acordo com Vei, a Sol - uma representante menos contraditória do que Macunaíma dos valores autóctones -, ao não escolher uma de suas filhas para casar-se e, em vez disso, se amulherar "com uma portuguesa, o Portugal que nos herdou os princípios cristãos europeus" (SOUZA, 2003, p. 56), pois "o contato com o progresso modificara gradualmente o herói, habituando-o aos padrões europeus" (SOUZA, 2003, p. 56). Ele deveria ter escolhido uma das filhas de Vei para casar-se, pois assim acordaram após as filhas dela o recolherem tremendo de frio numa ilhota deserta da Baía de Guanabara, limparem-no, porem-no numa jangada e embalarem seu sono em carícias.

A traição é a primeira parte da contenda entre Vei e o herói. Mais adiante, Macunaíma está de volta à sua terra natal, à beira do rio Uraricoera, exausto e carcomido por maleita, com a muiraquitã, quando Vei resolve vingar-se. Acompanhemos as reflexões conclusivas de Gilda de Mello e Souza sobre o tema:

Vei sabe, portanto, que para ser bem-sucedida precisa europeizar também os instrumentos de castigo. E por isso empresta à miragem com o que o atrai a atonalidade geral europeia, fazendo a água "forçadamente fria naquele clima do Uraricoera e naquela hora alta do dia" e disfarçando a aparência ameríndia da Uiara sob os traços lusitanos de Dona Sancha. Macunaíma resiste durante algum tempo ao embuste, mas afinal acaba cedendo e "se atira na água fria, preferindo os braços da iara ilusória”. Então os bichos da água o reduzem a um "frangalho de homem" e ele perde para sempre a muiraquitã, "o amuleto nacional que lhe dava razão de ser".

Acompanhemos agora Mário de Andrade na explicação que nos dá de sua alegoria. As filhas de Vei - "filhas da luz", "filhas do calor" - representam as grandes civilizações 
tropicais como a Índia, o Peru, o México, o Egito, civilizações que se realizaram em torno de valores culturais muito diversos do Ocidente e que teriam se harmonizado melhor com as nossas condições geográficas e climáticas. Por conseguinte, posto na situação de escolher entre as filhas de Vei e a portuguesa (o Ocidente), Macunaíma devia ter optado pela primeira; esta seria a decisão acertada, coerente com a ação central do livro, a busca do amuleto. Agindo assim, o herói estaria inscrevendo o seu destino no âmbito do Uraricoera, dando coerência à luta com o gigante e fazendo jus à recuperação da muiraquitã. Enfim, estaria se esforçando por "se organizar numa vida legítima e funcional", que transformasse "o caos interior de suas disposições naturais num cosmo organizado em torno de um centro de gravidade". Ao contrário, a escolha que efetua inicialmente da portuguesa e, no final da narrativa, de Dona Sancha (pois ludibriado por Vei toma a uiara ameríndia por uma das filhas de mani) - estava em desacordo com a aventura em que se lançara: representava uma acomodação aos princípios cristãos europeus e estabelecia, portanto, uma relação desarmoniosa entre o núcleo de sua personalidade e uma civilização que correspondia a "outras necessidades sociais e outros climas" (SOUZA, 2003, p. 56-57).

Notamos que se, por um lado, Macunaíma enfrenta o gigante num embate entre autóctone e estrangeiro, cede aos encantos da portuguesa e da Uiara europeizada, traindo Vei, representante dos valores dos trópicos.

Parece-nos, portanto, que Macunaíma tem a característica trickster em análise, pois vive na fronteira, transitando de forma ambígua entre mundos e fazendo a ligação entre eles. Ao retornar ao Uraricoera com aparatos da metrópole, ele está sendo um mediador entre os dois mundos. Assim como o é em diversos momentos em que está em São Paulo e age como se estivesse na floresta, chegando a explicar, na forma da mitologia indigena, a formação do Cruzeiro do Sul. Cumpre a mesma função ao escrever a "carta pras Icamiabas", momento em que leva a linguagem empolada do brasileiro europeizado para o fundo do mato virgem, onde nasceu e para onde retornará, carregado de carga metropolitana. Usará os apetrechos dos brancos, contudo, como bem entende, como faz ao transformar revólver e relógio em brinco, numa postura que se pode 
chamar de antropofágica, única saída para o habitante do entre-lugar cultural que habitam o brasileiro, espremido entre o índio, o negro e o europeu, e também Macunaíma, que antropofagicamente faz a mediação entre estas culturas, em uma atuação tipicamente tricksteriana.

\subsection{2 - Makunaima}

Assim como fizemos na análise desta característica no Macunaíma marioandradiano, voltamos a referenciar a tese de Silvia M. S. de Carvalho. Como já explicitado, o ser humano vive em uma relação de tensão com a natureza, tendo que extrair dela sua subsistência. Contudo, caso exagere na punção, faltarão alimentos. Por isso o trickster age ora como ao lado do ser humano, ora como ao lado do "outro", ou seja, da natureza.

No famoso relato do antropólogo alemão Koch-Grünberg podemos extrair algumas ações mediadoras. "Makunaíma fez todos os animais de caça e os peixes” (KOCH-GRÜNBERG, 2002, p. 66), ou seja, criou seres da natureza benéficos ao ser humano, de que este se vale para realizar a punção necessária, mas, por outro lado, fez animais perigosos como a arraia; seu irmão Jigué, como colocado por Silvia M. S. Carvalho, espécie de alter ego do trickster em comento (KOCH-GRÜNBERG, 2002, p. 66), fez a cobra venenosa, embora haja igualmente versão que afirma ter sido criada pelo próprio Makunaima (KOCH-GRÜNBERG, 2002, p. 66 e nota de rodapé). Ele também se transformou em um animal nocivo, qual seja, o bicho-de-pé.

Makunaima demonstra, ainda, ser um ente da natureza ao transformar-se em grilo (KOCH-GRÜNBERG, 2002, p. 66) e ao viver numa montanha junto a diversos bichos-de-pé (KOCH-GRÜNBERG, 2002, p. 68). No mito "Morte e ressurreição de Makunaíma", o herói, depois de ser morto pelo gigante Piai `mã, é ressuscitado com a ajuda de alguns animais.

Entendendo-se a natureza como outro em oposição ao ser humano, ele também pode ser visto como um aliado desta sempre que se opõe às pessoas. Alguns exemplos: cria feridas no próprio corpo, depois cansa delas, as atira no chão e as transforma em pedra, dizendo "'ficai aqui! Pegai em toda gente que passar por aqui!' Por isso aqueles que usam esse caminho hoje, ficam com feridas" (KOCH-GRÜNBERG, 2002, p. 67). Ele transforma várias pessoas que participavam de uma cerimônia dançante em pedra (KOCH-GRÜNBERG, 2002, p. 67). Em outra ação contra o homem e a favor da natureza, ele transmuta pessoas que queriam ir para casa em 
cupim e, depois de deixar pegadas de veados, antas e todos os animais dando a entender que se transformara neles -, vira outros homens em pedras (KOCH-GRÜNBERG, 2002, p. 68). Ele leva sua mãe, a casa e as plantações para o pico da montanha, deixando o resto da família sem nada para comer. Ao fazer isso, ele protege os alimentos contra a sanha dos irmãos, agindo, portanto, a favor do outro e contra os humanos $(\mathrm{KOCH}$ GRÜNBERG, 2002, p. 67). Outro exemplo:

Quando Jigué pulou dentro d’água, Makunaíma quebrou uma folha da planta Makumúku-yeg, jogou-a na água e disse: 'Transforma-te numa arraia e vai para junto de Jigué! Quando ele pisar em cima de ti, pica-o!” Makunaíma ficou na entrada da baía e disse a Jigué: "Vem mais pra cá, para espantar os peixes!" Jiguê veio pisou nela. A arraia picou-o no pé. Jigué gritou muito (KOCH-GRÜNBERG, 2002, p. 67).

Mas Makunaima, ao mesmo tempo em que é uma entidade da natureza, também é uma pessoa e, como tal, precisa realizar punção da natureza para alimentar-se, então age muitas vezes contra esta. Por isso, apanha os animais que seu irmão Ma anápe abate com a zarabatana. Ele também demonstra ser um ente ao lado do humano por ser um heróicivilizador, que fornece tecnologias fundamentais para o desenvolvimento da cultura humana.

É emblemático um trecho da mitologia pemon de que se vale Mário de Andrade e já citado também quando analisamos o caráter mediador de Macunaíma. Referimo-nos à transformação do herói em peixe aimará, para roubar o anzol do pescador. Depois de duas tentativas frustradas, ele transforma-se em piranha para arrancar-lhe o anzol com a dentição. Neste mito, ele demonstra ser um ente da natureza, não à toa vira duas espécies distintas de peixe e age contra o pescador, ao mesmo tempo em que busca facilitar a punção da natureza pelo humano, pois vira peixe para obter o anzol que permitirá uma pesca mais fácil. Seu caráter mediador escancarase neste ponto. Em síntese, Makunaima é ao mesmo tempo gente e natureza e, atuando ora a favor de um, ora de outro, acaba por ser um mediador entre estas duas realidades.

Contudo, não é apenas atuando a favor que ele exerce a mediação. Makunaima tem o hábito de transformar diversas coisas em pedra. Esse mito, muito provavelmente, deriva do fato de a região do Monte Roraima 
ser tomada por diversas rochas de formatos curiosos. Ele transmuta indiscriminadamente pessoas e entes da natureza em rochas. Trata-se de uma representação de seu lado traiçoeiro e ambíguo, lembrando que, se, por um lado, ele é aliado do ser humano e da natureza, é simultaneamente inimigo dos dois (no idioma pemon: Maku = mau; Ima = grande. "Assim o nome significaria ' $O$ grande mau', que calha perfeitamente ao caráter intrigante e funesto deste herói”; MEDEIROS, 2002, p. 33). Leiamos:

Makunaíma foi então para o outro lado do Roraima, onde deve estar vivendo até hoje. Lá ele transformou em rochedos homens e mulheres, bem como saúvas, antas e porcos do mato (KOCH-GRÜNBERG, 2002, p. 67)

Makunaíma, porém, transformou tudo o que encontrou, homens e animais, mutum, veados, porcos, garças, etc, em pedras, árvores e florestas. E tudo continua assim até hoje (...). Então Makunaíma foi para a montanha Mairari, onde deixou uma cabaça e um tipiti cheio de massa de mandioca. Estas coisas ele também transformou em pedra, e até hoje estão lá (KOCH-GRÜNBERG, 2002, p. 67)

\section{2 - SUAS AÇÕES CRIAM TABUS?}

\subsection{1 - Macunaíma}

Haroldo de Campos, em Morfologia do Macunaima, afirma que o livro de Mário de Andrade contém, sobretudo nos primeiros capítulos, "microfábulas" ou "micro-sequências", moldadas no esquema "interdito" /"violação" (CAMPOS, s/d, p. 126-127). Ele analisa, sobretudo, dois microepisódios:

a) Macunaíma flecha uma veada parida/ Mata a mãe;

b) Macunaíma possui Ci, rainha das Amazonas/ Ci morre.

No primeiro, a proibição de abater a caça prenhe constitui a moral da fábula indígena recolhida por Couto Magalhães e na qual Mário de Andrade se baseia nesta passagem. Ao violar o interdito, Macunaíma mata a mãe. A despeito de a interdição existir na lenda indígena usada como inspiração, ela surge no universo ficcional a partir da ação do herói. Ao matar a veada parida, ele é castigado com a morte da própria mãe. $\mathrm{O}$ surgimento do castigo a partir de uma ação corresponde ao nascimento de 
um tabu, já que o tabu nada mais é do que uma proibição e proibições efetivas demandam a existência de um castigo correspondente.

A mesma lógica se aplica ao fato de Macunaíma possuir $\mathrm{Ci}$, conforme se atesta na seguinte afirmação de Haroldo de Campos:

$\mathrm{Na}$ micro-sequência de $\mathrm{Ci}$, a proibição não-escrita, mas presente no espírito da lenda, é a do casamento com a celibatária rainha das amazonas, tribo de mulheres solitárias. $\mathrm{Na}$ lenda taulipang, coligida por KG (p. 127-128), as amazonas podem ter relações eventuais com homens que visitem suas malocas, mas não lhes é lícito casar-se (estabelecer relações duradouras), sendo vedado aos companheiros de ocasião permanecer no convívio da tribo; os filhos-varões que resultem dessas uniões são sacrificados, só sendo poupadas as filhas. Tomando-a primeiro à força, mas logo consentidamente, a rainha das amazonas e desposando-a, Macunaíma se transforma no "Imperador do Mato-Virgem" e passa a viver entre as icamiabas (CAMPOS, s/d, p. 128).

Posteriormente, Macunaima tem um filho com Ci que, todavia, morre. Ao viver com Ci, Macunaíma quebra o tabu mitológico e, na narrativa, cria a ação de casar-se com a rainha das amazonas. É punido por isso, com a morte do filho, trazendo (criando), assim, para o universo ficcional, a proibição que existia na cultura Taurepang.

Portanto, nota-se que efetivamente tabus são criados em função de ações de Macunaíma.

\subsection{2 - Makunaima}

Makunaima derrubou a árvore Wazaká, também chamada de Árvore do Mundo, que dava todos os frutos. Do buraco no tronco da árvore jorrou uma enorme quantidade de água, provocando uma enchente de proporções bíblicas. Depois que as águas secaram houve um incêndio universal. Salvo pelas caças, que se esconderam num buraco dentro da terra, "o fogo consumiu tudo: os homens, as montanhas, as pedras" (KOCH-GRÜNBERG, 2002, p. 65).

Não há, na mitologia pemon, referência a um tabu relativo à derrubada de árvores. Contudo, devemos lembrar que, no terreno da 
mitologia, os seres e ações são arquetipicos e exemplares. Desse modo, se a derrubada de uma árvore (arquetípica) teve a consequência da extinção da humanidade, podemos assumir que se criou, com base nesta história, um tabu quanto à derrubada de árvores frutiferas. Sílvia M. S. Carvalho de fato afirma a existência de tal tabu. Segundo a autora, "este mito representa a desobediência a um tabu que proibia o corte de árvores" (CARVALHO, 1997, p. 59). Diríamos, contudo, que, como estamos no terreno mitológico, essa história não apenas representa a desobediência ao tabu, mas funda o tabu. É que todas as ações e interditos relevantes de uma sociedade dita "primitiva" precisam de um mito que os represente, que funde aquela ação ou proibição. As ações dos seres humanos, segundo Mircea Eliade, nada mais são do que uma repetição destes atos arquetípicos (ELIADE, 1992, p. 13).

Ressalte-se que a queda da árvore, por outro lado, gerou várias benesses. De seus galhos nasceram árvores frutiferas; junto com as águas que escaparam pelo seu tronco cortado surgiu uma abundância de peixes. Isso, contudo, não parece ilidir o tabu, uma vez que qualquer benefício é incapaz de suplantar a extinção da humanidade em função de seu ato. Parece-nos que tais acréscimos ao mundo são uma faceta do lado heróicivilizador de Makunaima, que estabelece diversos contornos do mundo, como veremos adiante.

\subsection{QUANDO SÃO HERÓIS-CIVILIZADORES, GERAM PRODUTOS FUNDAMENTAIS AO FLORESCIMENTO DA CULTURA HUMANA?}

É importante ressaltarmos que não necessariamente um trickster é um herói-civilizador, embora seja comum que o seja. Por isso esta premissa inicia-se com uma condicionante: "quando é". Somente os tricksters transformers, ou seja, os que causam alterações no mundo, de modo a deixálo como o conhecemos, permitindo o florescimento de culturas humanas, são heróis-civilizadores.

\subsection{1 - Macunaíma}

Macunaíma é, efetivamente, iniciador de algumas coisas. Fatos acontecem com ele ou a partir de suas ações que passam a se aplicar a toda a humanidade. Isso o aproxima dos personagens mitológicos, uma vez que realiza ações arquetípicas que passam a ser repetidas por todos. Além disso, 
características do universo existem graças às suas ações. Cite-se como exemplo que a própria lua surge após um embate entre Macunaíma e Capei. E as manchas do satélite existem porque Macunaíma "deu uma porção de munhecaços" (ANDRADE, 1997, p. 124) nele. Macunaíma estabeleceu, dentre outras, as seguintes realidades no mundo:

a) as caças têm bexiga graças a Macunaima. Depois de tocar uma violinha mágica e atrair um despropósito de caça, o herói fica com medo de tamanha bicharada e atira a viola longe.

A violinha caiu no dente de um queixada que tinha umbigo nas costas e se partiu em dez vezes dez pedaços que os bichos engoliram pensando que era gerimum. Os pedaços viraram nas bexigas das caças (ANDRADE, 2007, p. 191).

b) a flor miosótis existe graças a uma ação do herói. Ele chora de saudade de $\mathrm{Ci}$, sua amada, e, por conta disso: "As lágrimas pingavam dos olhinhos azuis dele sobre as florzinhas brancas do campo. As florzinhas tingiram de azul e foram os miosótis" (ANDRADE, 2007, p. 207);

c) a Sol fica amarela após Macunaíma arremessar um ovo contra ela (ANDRADE, 2007, p. 206).

Macunaíma, portanto, estabelece alguns dos contornos que o mundo tem, contudo, não se pode dizer que ele seja um elemento fundamental da configuração geral do mundo. É determinante no estabelecimento de apenas alguns aspectos específicos. Tampouco os produtos de suas ações parecem ser de grande importância para o ser humano. Um típico herói-civilizador gera produtos - como tecnologias e alimentos - fundamentais para a existência da cultura humana, o que não ocorre com Macunaíma.

Parece-nos, pelo exposto, que o herói sem nenhum caráter é um transformer de poder limitado, uma vez que transforma o mundo em determinados pontos, mas sem alterar sua configuração como um todo. Não chega, deste modo, a ser um herói civilizador, pois não há qualquer ação sua que tenha resultado num produto essencial para o desenvolvimento da cultura humana.

\subsection{2 - Makunaima}

Graças a Makunaima, os seguintes produtos da natureza e tecnologias existem ou são acessiveis ao ser humano: 
a) o fogo:

Procuraram o fogo e acharam o passarinho Mutúg, que, segundo se dizia, tinha o fogo. $O$ pássaro estava pescando Makunaima amarrou-lhe um comprido cordel ao rabo, sem que ele o notasse. Logo o pássaro se assustou, levantou voo e levou o cordel consigo. Os irmãos seguiram o cordel e acharam a casa do Mutúg. Eles levaram então o fogo. (Talvez o tenham levado à força.) (KOCH-GRÜNBERG, 2002, p. $60)$.

b) o Monte Roraima e demais tepuis ${ }^{105}$ da região, sendo Makunaima responsável pela fertilidade do lado norte, como consequência da derrubada da Árvore do Mundo e de outras grandes árvores que se encontravam à volta dela:

(Seus tocos formam hoje as motanhas Elu-tepe e Yuluwazaluimá-tepe. $\mathrm{O}$ toco da árvore Wazaká forma o Roraima. Todas estas montanhas têm o mesmo formato e são muito altas.) As árvores caíram todas para o outro lado $^{106}$. Por isso ainda hoje existem por lá muitas bananas, milho, algodão e muitas frutas silvestres $(\mathrm{KOCH}-$ GRÜNBERG, 2002, p. 61).

c) a inajá, ao garantir a fertilidade desta fruta:

Então Jigué lhe deu uma fruta. Makunaíma tirou uma dentada, esfregou a fruta no próprio pênis e a devolveu a Jigué, dizendo: "Experimenta-a agora!" (Até hoje a Inajá dá frutas na época das chuvas.) (KOCH-GRÜNBERG, 2002, p. $61)$.

d) os seres humanos. Depois de estes terem sido consumidos pelo incêndio universal que se seguiu ao dilúvio provocado pela derrubada de Wazaká, foram recriados por Makunaima, que nessa

\footnotetext{
105 Substantivo comum empregado pelos pemon para designar os montes da região onde vivem.

${ }^{106} \mathrm{O}$ lado norte.
} 
história, como ser dúbio que é, mostra-se como destruidor e criador da humanidade:

Quando a água da grande enchente secou, veio um grande fogo. (...) $\mathrm{O}$ fogo consumiu tudo: os homens, as montanhas, as pedras. (...)

Makunaíma fez novos homens de cera. Mas eles se derreteram ao Sol. Então ele os fez de barro. Estes, expostos ao Sol, endureceram cada vez mais. Depois ele os transformou em gente (KOCH-GRÜNBERG, 2002, p. 64).

e) todos os animais de caça e os peixes (KOCH-GRÜNBERG, 2002, p. 66);

f) o anzol, conforme a história a que nos referimos em 2.1.2, sobre o furto do anzol (KOCH-GRÜNBERG, 2002, p. 66-67);

g) a arraia. A cobra venenosa é criada, no mesmo mito, pelo seu alter-ego e irmão Jigué (KOCH-GRÜNBERG, 2002, p. 71-72).

Como se nota, Makunaima é responsável por diversos contornos do mundo. Contudo, tal não basta para que seja herói-civilizador, pois é necessário que as alterações provocadas no mundo pelo ser sejam fundamentais para o florescimento da cultura humana. Como o herói em comento foi o criador de todos os animais de caça e peixes, além de ter trazido para o ser humano o anzol e o fogo, seria difícil a sobrevivência da cultura pemon sem ele. Por mais que os pemon se valessem de uma alimentação vegetariana, ainda assim, é graças a Makunaima que existe abundância de alimento vegetal no lado norte do Monte Roraima, onde talvez a caça seja dispensável para a sobrevivência. Como visto acima, o próprio ser humano foi criado pelo herói, mas esta responsabilidade pela existência da humanidade fica mitigada, uma vez que o ser humano existia independente de Makunaima, tendo sido, contudo, destruído por uma ação deste ser mítico e aí sim, posteriormente recriado por ele.

Uma vez que Makunaima é responsável pela existência do alimento e de tecnologias de que se vale o ser humano para melhor punção da natureza, não há dúvida de que ele é elemento fundamental para o florescimento da cultura humana, sendo, portanto, um típico heróicivilizador.

\section{4 - É LIGADO AO DESLOCAMENTO?}

\subsection{1 - Macunaíma}


Segundo Eduardo Subirats, Mário de Andrade já definiu Macunaíma como "homem itinerante sem vontade" (SUBIRATS, 2014, p. 248, 286). Tal itinerância é de clareza solar. Na primeira parte do livro, antes de Macunaíma partir para São Paulo em busca de sua muiraquitã, a narrativa tem um formato rapsódico, em que histórias se sucedem, muitas delas graças a um constante deslocar-se do herói. Logo no início do livro desloca-se, junto com sua mãe e sua casa, para outra banda do rio, escapando de inundação e fome (ANDRADE, 2007, p. 23). Como deixara o resto da família passando fome, a mãe expulsou o herói, que começa, então, sua errância rapsódica, algo comum aos tricksters. Enquanto vagava, Macunaíma encontrou o Curupira e fugiu dele; deparou-se com a cutia, que jogou água em seu corpo, fazendo-o pôr corpo de homem; conheceu sua amada $\mathrm{Ci}$, a mãe do mato, com quem viveu até a morte dela. Falecida a esposa, o herói volta a errar e tem o encontro com Capei, cuja cabeça acaba por tornar-se a lua, após um embate com o herói. Depois disso, descobriu que a muiraquitã estava com o industrial Venceslau Pietro Petra, em São Paulo, e deslocou-se para lá.

Há uma certa magia no deslocamento de Macunaíma, um desrespeito à geografia nacional, que se embaralha sob as aventuras do herói. O próprio Mário de Andrade escreveu em uma folha de um bloco de notas: "Contar a embrulhada geográfica proposital de fauna e flora" (ANDRADE, 2007, p. 221). Macunaíma mistura os lugares e, com isso, a fauna e flora. Ele dá "uma chegada na foz do rio Negro pra deixar a consciência na ilha de Marapatá" (ANDRADE, 2007, p. 49) e enquanto é perseguido por um cachorro passa por lugares tão distantes quanto Itamaracá e os Pampas. Semelhante dinâmica ocorre quando ele foge do monstro do Oibê, no capítulo "A pacuera do Oibê". Não bastasse, vai até o Rio de Janeiro para uma sessão de macumba e, por fim, faz uma viagem de regresso ao Uraricoera.

Nota-se que, durante o vagar, Macunaíma desenvolve sua astúcia, como quando escapa do Curupira vomitando em uma poça o pedaço de carne da perna do monstro que respondia aos seus chamados, denunciando a localização do herói. É também vagando que Macunaíma conhece $\mathrm{Ci}$, com quem vive seu único relacionamento amoroso (além desta relação, só há aventuras sexuais) e que lhe dá uma muiraquitã. Na saga pela recuperação deste talismã, o herói, pela primeira e única vez, terá foco e algum sentido de praticidade. 
Conclui-se, portanto, que o se deslocar e o se deparar com o novo fazem parte do processo de amadurecimento de herói, mesmo que ao fim, como se verá, tal processo evolua pouco.

\subsection{2 - Makunaima}

Após a enchente e o incêndio universal, Makunaima desloca-se para o outro lado do Roraima (KOCH-GRÜNBERG, 2002, p. 65), ou seja, o norte (Venezuela), onde caíram os galhos de Wazaká e onde há muitas frutas e tubérculos. Em outro mito ele também se desloca para o outro lado, para a Terra dos Ingleses (Guiana), na forma de grilo, dentro da cesta do pescador, para adquirir novo anzol (KOCK-GRÜNBERG, 2002, p. 67). Em comum a ambos os deslocamentos, a busca por alimento depois de o alimento do lado "de cá" do Monte Roraima haver escasseado por conta do desastre ocorrido após a derrubada da Árvore do Mundo. Agora com escassez de alimento, o herói terá que lutar para consegui-lo, valendo-se, inclusive, de astúcia para tal, como faz ao transformar-se em grilo para entrar no cesto do pescador e ser levado, sem esforço, para o outro lado.

Outro momento de grande deslocamento é quando foge do cachorro de Piai `mã. O cão representa a natureza aliada do homem, ao passo que Makunaima é mediador entre natureza como outro, ou seja, a natureza inimiga, e o homem. Ele é inimigo e aliado, simultaneamente, da natureza e do ser humano, nesta relação tensa entre a humanidade e a natureza. Esta natureza aliada é estranha ao herói-mediador. O ponto de mediação surge, no plano simbólico, pelo fato de Makunaima agir, muitas vezes, a favor do homem e contra a natureza, ele que é - ao mesmo tempo em que é gente - um ser da natureza. O cachorro, que é natureza, também age o favor do ser humano, podendo ser interpretado, igualmente, como um mediador. Mas um mediador menos contraditório, que propõe uma aliança, quando não uma submissão. No entanto, o pemon sabe que esta aliança não é possivel, que, se a natureza fornece os insumos necessários para a sobrevivência, ela não é submissa ou confiável. Makunaima é um mediador que representa a natureza de forma mais real do que o cachorro e por isso consegue sobreviver às investidas deste (KOCK-GRÜNBERG, 2002, p. 73-74).

2.5 - CAMINHA PELO MUNDO PRIMEIRAMENTE NUM ESTADO
QUASE INCONSCIENTE E, ATRAVÉS DA CONTENÇÃO DE SEUS
DESEJOS, DESENVOLVE UMA INTELIGÊNCIA ASTUCIOSA, 
ATRAVÉS DA QUAL OBTÉM SEUS OBJETIVOS DE FORMA AÉTICA E DESPRENDIDA DA ORDEM DO COSMO EM QUE SE ENCONTRA, FREQUENTEMENTE FAZENDO USO ESQUIVO DA LINGUAGEM E DE UM ESTILO BUFÃO? É MUTANTE, SEM CARÁTER DEFINIDO, COM GRANDE CAPACIDADE DE ADAPTAÇÃO?

\subsection{1 - Macunaíma}

Para desdobrar este tópico, vejamos alguns exemplos de ações de Macunaíma nas quais ele demonstra astúcia e capacidade de adaptação:

a) transforma-se em francesa para enganar Piaimã (ANDRADE, 2007, p. 64);

b) tenta enganar o Pai do Sono, fingindo-se de morto (ANDRADE, 2007, p. 162);

c) três vezes transforma-se em aimará para concluir que não conseguirá roubar o anzol desta maneira, uma vez que tal peixe não possui dentição para arrancar o anzol. Vira, então, uma piranha, mimetizando sua capacidade de morder, mas acrescentando a essa capacidade a astúcia, para arrancar o anzol, tomando-o para si (ANDRADE, 2007, p. 132).

Macunaíma tem, como se nota, a capacidade de usar astúcia para conseguir seus objetivos, sobretudo mimetizando algo, seja transformandose efetivamente na coisa ou adotando uma ação típica dela.

Os ardis do trickster dão-se principalmente pela imitação de outros seres. Ele segue um ciclo. Primordialmente vaga pelo mundo em estado de grande inconsciência, a ponto de suas mãos brigarem até que ele se machuque, somente então percebendo que ambas fazem parte do seu corpo, como faz o trickster do povo winnebago. Ele está, no primeiro momento, aquém dos animais, já que estes têm um jeito nato de agir, estratégias de sobrevivência pré-determinadas pelo instinto. $O$ trickster, contudo, no início não as possui, mas é capaz de observar e apreender técnicas de animais e utilizá-las não por instinto, mas por astúcia - de que os animais não são capazes -, aprimorando sua eficácia e tornando-se superior a eles.

É o que faz Macunaima, por exemplo, quando, depois de se transformar em aimará três vezes e não conseguir roubar o anzol que deseja, vira uma piranha e, usando os dentes de tal peixe e a sua astúcia, arranca o anzol da linha e dele se apodera. Macunaíma tem uma atitude típica de trickster no trecho citado. Ele aprende por tentativa e erro e então adapta a ação, encontrando uma solução eficaz. 
Fundamental na evolução do trickster é a contenção dos desejos, sobretudo o sexual e, ainda mais, por alimento, uma vez que, em caso de desejo alimentar incontido, a comida tornar-se-á escassa. O herói andradiano, contudo, não parece ser afeito a contenções. Mais de uma vez deixa de repartir a comida com seus irmãos, chegando a enganá-los para ficar com toda a provisão. Tampouco poupa uma veada parida e, por conta disso, mata a própria mãe. É lavado e recebe carinho das filhas de Vei, a Sol, que lhe faz uma grande proposta em troca do casamento dele com uma de suas filhas:

Oropa França e Bahia. Mas porém você tem de ser fiel e não andar assim brincando com as outras cunhãs por aí.

Macunaima agradeceu e prometeu que sim jurando pela memória da mãe dele (ANDRADE, 2007, p. 90).

Contudo, logo em seguida, à vista da primeira cunhatã, o herói não se contém e trai o acordo, perdendo "Oropa França e Bahia". Com isso, transforma Vei em inimiga. A Sol, mais à frente, ciente da falta de contenção do herói, usa tal fraqueza como arma para desgraçá-lo. Envia uma Uiara para seduzi-lo e, por não se conter e entregar-se à sereia amazônica, Macunaíma termina mutilado e sem a muiraquitã.

Nota-se, portanto, que Macunaíma chega ao fim do livro sem ter aprendido a contenção, sendo ainda um trickster ingênuo, de ciclo incompleto. Contudo, ele é inegavelmente astuto. Mas, se a astúcia do trickster depende da consciência que adquire da necessidade de contenção de suas pulsões, de onde viria a astúcia do herói incontido?

Embora Macunaíma não aprenda a restringir seus desejos, sobretudo os sexuais, ele elabora planos, principalmente para resgatar a muiraquitã em poder de Piaimã. A simples elaboração de planos exige uma mínima contenção, uma vez que aquele que age puramente por impulso não planeja, apenas pratica uma ação na primeira oportunidade que surge. O herói, contudo, parece ter ao menos uma consciência da necessidade de contenção, a qual ele consegue exercer para executar seus planos. Esta consciência fica clara quando ele aconselha ao tuiuiú:

- Olha, primo, pagar não posso não mas vou te dar um conselho que vale ouro: Neste mundo tem três barras que são a perdição dos homens: barra de rio, barra de ouro e barra de saia, não caia! 
Porém estava tão acostumado a gastar que esqueceu-se da Economia (ANDRADE, 2007, p. 138).

Macunaíma percebe o perigo das tentações e a necessidade de constrição. Contudo, "tão acostumado a gastar esqueceu-se da Economia", ou seja, logo após aconselhar a contenção, ele próprio paga ao tuiuiú, deixando de restringir-se e economizar.

É desta consciência da necessidade de contenção que o herói se vale para ser astuto. Ele chega a exercer um básico nível de contenção quando está em busca da muiraquitã. O objeto de seu desejo é a única coisa capaz de fazê-lo agir de uma forma minimamente funcional, mas, assim que ele o recupera, torna a ser exclusivamente guiado pelo princípio do prazer. Tal comportamento determina sua derrota ao final.

A ausência de caráter definido, proclamada no próprio título da obra, faz com que o protagonista não tenha uma ética determinada, permitindo-lhe agir da maneira que lhe agrada em cada situação específica, rompendo os limites de qualquer moral. Esta falta de caráter faz dos tricksters seres do limiar, pois quem está no limiar não está comprometido com nenhum lado e pode apenas observar sem envolvimento "las contigencias humanas" (SUBIRATS, 2014, p. 257), como ocorre logo no início da vida do herói, em que ele "Ficava no canto da maloca, trepado no jirau de paxiúba, espiando o trabalho dos outros" (ANDRADE, 2007, p. 13).

Aquele que é sem caráter e ambíguo será mutante, pois a mutação deriva da própria instabilidade: "A metamorfose é desordem, regressão e transgressão" (VIVEIROS DE CASTRO, 2002, p. 73). Portanto, a natureza mutante manifesta-se no próprio estilo contraditório. Será, contudo, também física. Basta lembrarmos que o herói se transforma em peixes, formiga e francesa.

Uma leitura interessante, trazida à baila por Eneida Maria de Souza, nos autoriza dizer que Macunaíma é, também, um trickster linguístico. $\mathrm{O}$ uso esquivo da linguagem encontra-se em vários tricksters e é de onde, em geral, deriva o jeito bufão. Como soem fazer os tricksters, Macunaíma desrespeita convenções pré-estabelecidas. No campo da linguagem isso se dá por uma alienação quanto às relações signo-referente consagradas, lembrando-nos que não há um elo lógico ou natural entre significantes e significados. Nas palavras da autora mencionada: 
É possivel afirmar que a produção textual de Macunaíma põe em causa a pretensa propriedade do discurso, conseguido graças ao comportamento impróprio da personagem frente aos signos, apontando, assim, a ausência de elo entre signo e referente (SOUZA, 1999, p. 51).

A prática linguística repetitiva consiste no questionamento da linguagem, considerando-se que os signos, desprovidos de sentido fixo e estereotipado, são como moedas que circulam, veiculando um número infinito de significações. $\mathrm{O}$ olhar distanciado do sujeito em relação às palavras vem comprovar a ilusão de existir um elo natural entre o signo e o referente. Macunaíma, ao revelar a tendência de tomar as palavras sempre ao pé da letra, no intuito de provar que elas são o reflexo das coisas, permite que se interprete a atitude imprópria frente aos signos como negação da propriedade que os signos reivindicam sobre seus referentes (SOUZA, 1999, p. 47).

A interpretação ao pé da letra dos signos, contudo, não é apenas uma "negação da propriedade que os signos reivindicam sobre seus referentes", mas também os transforma em "manifestações concretas capazes de transformar a realidade" (SOUZA, 1999, p. 115), como ocorre no trecho em que o herói atira palavrões em Venceslau Pietro Petra, como se fossem pedras e, assim, "a linguagem torna-se ação" (SOUZA, 1999, p. 132):

Então Macunaíma pegou na primeira palavra-feia da coleção e jogou na cara de Piaimã. O palavrão bateu de rijo porém Venceslau Pietro Pietra nem se incomodou, direitinho elefante. Macunaíma chimpou outra bocagem mais feia na caapora. A ofensa bateu rijo porém se incomodar é que ninguém se incomodou. Então Macunaíma jogou toda a coleção de bocagens e eram dez mil vezes dez mil bocagens (ANDRADE, 2007, p. 130).

Como um típico trickster, o herói marioandradiano distorce a lógica do cosmo em seu benefício. Faz um furo no tecido de possibilidades ao subverter a linguagem e transformá-la em arma concreta. Ele tem uma 
relação subversiva com a linguagem desde seu nascimento, conforme observa Subirats:

Simplemente se niega a hablar. Y esta rebelión lingüistica del joven Macunaima es sólo el primero de una serie de desacatos semiológicos, sabotajes semánticos y atentados gramaticales, así como invenciones y regurgitaciones en y contra el sistema de la langue (SUBIRATS, 2014, p. 253).

Sabotagem que se inicia desde o seu nascimento, ao se recusar a falar, e que encontra seu ápice na transformação de signos em objetos concretos, no trecho acima destacado.

Concluímos, por fim, que Macunaíma possui as características trickster deste tópico, uma vez que usa de astúcia por meios aéticos para atingir seus objetivos. É, sem dúvida, mutante e possui grande capacidade de adaptação. O próprio uso da linguagem como forma de atacar um adversário fisicamente superior, o que faz ao arremessar palavrões contra o gigante, é um exemplo de sua grande capacidade adaptativa.

Reconhecemos, contudo, que "o herói de nossa gente" não concluiu seu ciclo, não tendo atingido a contenção de desejos necessária para que se tornasse astucioso o suficiente para cumprir sua missão de manter a muiraquitã no retorno ao Uraricoera. Foi justamente esta falta de contenção que impôs sua derrota, uma vez que não se deteve ao trair a promessa feita para Vei e deitou-se com uma portuguesa tão logo a Sol e suas filhas lhe deram as costas. A traição incitou o desejo de vingança em Sol, que enviou uma Uiara para desgraçar o herói. Novamente ele não resistiu à tentação e, por isso, teve sua derrota final ao perder a muiraquitã e ser mutilado. Não acreditamos, contudo, que o fato de Macunaíma não ter alcançado o mesmo grau de contenção e de astúcia atingido pela maioria dos tricksters mitológicos lhe retira a qualidade de trickster, uma vez que, de todo modo, ele é astucioso, tem grande capacidade adaptativa e age de forma aética. Apenas o grau de sua astúcia não atingiu patamares elevados o suficiente para se adaptar da melhor forma possivel ao mundo, como acabam por fazer os tricksters. Eles, na maioria dos mitos, começam praticamente na inconsciência e por isso passam por maus bocados. Vão, contudo, contendo seus desejos e aprendendo técnicas astutas até que se adaptam ao seu entorno, servindo de exemplo aos humanos. Macunaíma, contudo, não desenvolve a contenção necessária para se tornar astuto o suficiente para lidar bem como o mundo que o cerca, por isso, após perder 
a muiraquitã pela segunda vez e ser mutilado, desiste dele, retirando-se para o cosmo. Em síntese, Macunaíma, o trickster modernista, foi derrotado pela falta de contenção de suas pulsões, sobretudo a pulsão sexual.

\subsection{2 - Makunaima}

Vemos, em Makunaima, momentos de ingenuidade - muitas das vezes causada por falta de contenção de suas pulsões - e de astúcia, ou seja, os dois momentos do ciclo trickster. A mais emblemática ação do herói, no que tange à falta de constrição, é a derrubada da Árvore do Mundo, que fornecia todos os frutos. Não satisfeito em comer apenas as frutas que dela caíam, como recomendou seu irmão mais velho Jigué, Makunaima decide derrubar a árvore, o que lhe daria acesso imediato a todos os frutos dela, a despeito do alerta do irmão: "Não! Não derrubemos também esta árvore, senão ficaremos outra vez sem comer!" (KOCH-GRÜNBERG, 2002, p. 60). Com isso, o alimento passa a ser limitado, sendo necessária astúcia para obtê-lo.

Em outro mito, Makunaima é engolido por Waimesá-pódole, o pai da lagartixa (na verdade, uma lagartixa arquetípica), por não aguentar a curiosidade:

Ninguém podia se aproximar dele, porque tinha uma língua muito comprida, com a qual pegava todos os animais. Makunaíma disse: "Quero ver!” Ma nápe disse: "Não! Ele vai te engolir!" Makunaíma respondeu: "Não! Eu quero ver!” Ma nápe disse mais uma vez: "Olha, o bicho vai te pegar, meu irmão!” Mas Makunaíma não deu importância ao conselho. Então Ma nápe deixou-o ir. Makunaíma foi lá para ver. Aproximou-se de Waimasá-pódole, que o pegou com a língua e o engoliu (KOCH-GRÜNBERG, 2002, p. 76).

O exemplo acima é sintomático de uma característica do herói: "quando Makunaíma queria alguma coisa ele insistia até conseguir" (KOCH-GRÜNBERG, 2002, p. 61-62). Isso significa dizer que Makunaima não se continha, ou seja, fatores exteriores não o bloqueavam, algo típico de um ser tomado exclusivamente pelo princípio do prazer, ainda infenso ao princípio da realidade. Por isso, por desejar sem restrições ou 
considerações, é que Makunaima derruba a árvore Wazaká e, em outra história, violenta a esposa de seu irmão:

Quando Makunaíma ainda era menino, chorava a noite inteira e pedia à mulher do irmão mais velho que o carregasse para fora de casa. Ele queria segurá-la e abusar dela. Sua mãe decidiu levá-lo para fora, mas ele não quis. Então a mãe mandou a nora levá-lo: ela o carrega para fora, afastando-se uma boa distância da casa, mas ele pediu que o levasse para mais longe. Então a mulher o levou para mais longe, para trás de um morro. Makunaíma ainda era um menino. Mas quando lá chegaram, ele se tornou um homem e abusou dela (KOCH-GRÜNBERG, 2002, p. 68).

Nota-se por essa ação e outras - como amarrar e deformar um jovem por cuja pretendente Makunaima era sexualmente interessado $(\mathrm{KOCH}$ GRÜNBERG, 2002, p. 72), ou a já citada transformação de diversos seres em pedra -, que o herói age de forma aética. Uma vez que é tomado pelo princípio do prazer, é guiado por suas pulsões, de modo que considerações externas aos seus desejos sequer se lhe apresentam; assim, a ele é inviável ter considerações éticas. Nada mais típico de um trickster, uma vez que estes seres têm justamente uma função de, por sua ação um tanto caótica e indiferente à moral vigente, pô-la em xeque, propondo, deste modo, uma constante atualização da moral social. Não que ao transgredir uma determinada regra o trickster esteja propondo a revogação daquela regra, ele apenas, por ser indiferente a ela, uma vez que não se submete à estrutura mental que rege os membros de uma sociedade, demonstra que há outras possibilidades de estruturas mentais e lógicas, desestabilizando e problematizando, por meio de ações não calculadas, o sistema.

Vejamos, agora, que Makunaima é mutante e astuto.

O primeiro ato de astúcia narrado pelo etnógrafo alemão é o furto do fogo, já transcrito no item “a” da subseção 2.3. Logo em seguida, fingindo que dormia, o herói consegue confirmar que Akúli comia, escondida, saborosas frutas (KOCK-GRÜNBERG, 2002, p. 60). No mesmo mito, é afirmado que "Makunaíma, o mais novo dos irmãos, era mais safado que todos os outros, embora fosse um menino. Os outros irmãos dependiam dele, pois lhes garantia seu sustento" (KOCHGRÜNBERG, 2002, p. 60). Neste trecho, a astúcia (gênero do qual a citada "safadeza" constitui uma espécie) é explicitamente posta como importante 
para a garantia do sustento, pois, num mundo de recursos limitados (nesta altura, Makunaima e seu irmão ainda não conheciam a árvore Wazaká), a astúcia é fundamental para o sustento. Por isso Makunaima sabe rastrear (KOCH-GRÜNBERG, 2002, p. 65) e domina técnica para cercar os peixes, facilitando a pescaria (KOCH-GRÜNBERG, 2002, p. 65). E justamente para a pesca é que Makunaima cria o anzol, primeiramente de cera, mas, percebendo que não funciona, vale-se de astúcia para subtrair o anzol de um pescador. Este mito, já referido em 2.2.2, traz um importante exemplo da típica evolução do trickster. Assim como o Macunaíma ficcional (Mário de Andrade valeu-se desse mito para narrar história praticamente idêntica), Makunaima tem uma atitude típica de trickster no trecho citado. Ele aprende por tentativa e erro e então adapta a ação, encontrando uma solução eficaz, ou seja, passa da ingenuidade e da falta de consciência para a ação pensada, astuta.

A astúcia é o ardil, a capacidade de enganar, logo demanda dissimulação. Aquele que está sempre dissimulando acaba por não ter um caráter definível, como é o caso dos tricksters. São, portanto, seres mutantes e ambíguos. Diz-se que são mutantes tanto por terem caráter ambíguo quanto por, muitas vezes, alterarem sua constituição física. Makunaima transforma-se em todos os animais. Ainda menino transmuta-se em homem feito para deitar-se com a mulher do seu irmão, em um primeiro momento violentando-a. Mas, num segundo momento, desejando-a ainda mais entregue e submissa, passa por mutações para, astutamente, fazê-la rir:

Um dia o irmão mais velho foi caçar com os outros irmãos, deixando em casa a mulher com o menino e a mãe. A mãe foi para a roça e Makunaíma ficou em casa, sozinho com a mulher. Transformou-se num bicho-de-pé para fazê-la rir. Mas ela não riu. Então ele se transformou num homem com o corpo todo coberto de feridas, porque queria que ela risse e se tornasse mais submissa. Então a mulher riu. Makunaíma caiu sobre ela e a possuiu.

O irmão mais velho sabia de tudo, mas preferiu ignorar, porque pensou na fome que tinha passado e também porque não podia viver sem o irmão mais moço. Por isso não quis mais brigar com ele (KOCK-GRÜNBERG, 2002, p. 70).

Lembrando que os mitos expressam valores fundamentais de uma sociedade, observa-se que a reação do irmão parece ser um reconhecimento, 
pelos pemons, da impossibilidade de sobrevivência sem a astúcia. $O$ ser humano consegue caçar e pescar não por uma superioridade física, mas por sua astúcia. O simples fato, que nos parece hoje tão corriqueiro, de colocar uma isca em um anzol, que simula uma presa do peixe, é uma típica ação astuta. Desse modo, como os seres mitológicos inauguram comportamentos, há um reconhecimento de que, sem a astúcia, ou seja, sem o trickster, não é possível o florescimento da cultura humana. Afinal, um dos diferenciais do ser humano é conseguir adaptar-se, ou seja, ter mobilidade, fazer ajuste nos planos, pois os animais considerados astutos não o são verdadeiramente: apenas seguem o instinto, só sabem agir daquela maneira. Caso por algum motivo o velho "plano" não funcione, serão incapazes de adaptá-lo e a suposta astúcia redundará em estupidez. É fundamental, portanto, para a verdadeira astúcia, a capacidade de adaptarse, de fazer mutações. E isso só o ser humano consegue realizar, graças aos aprendizados trazidos pelo trickster em tempo primordial. O ser humano imita os animais, mas está livre para valer-se de um ou outro subterfúgio daquele ou deste animal, de acordo com as circunstâncias. É essa capacidade de escolha da ação mimética mais apropriada ao momento que permite ao ser humano superar os animais.

Já a capacidade de adaptação deriva da própria astúcia e da mutabilidade. Ao transformar-se para melhor atingir um objetivo, Makunaima está sabendo adaptar-se. Desse modo, ao notar que, ao virar um bicho-de-pé, não consegue fazer a mulher de seu irmão rir, transformase num homem cheio de feridas; com isso o herói demonstra sua capacidade de adaptação, sua necessária maleabilidade. Há também outros momentos em que ele deixa clara esta capacidade, como no tão citado mito em que vira piranha para roubar o anzol depois de perceber que como aimará não conseguiria, ou quando cria homens de barro depois de os que fizera de cera derreterem ao sol (KOCH-GRÜNBERG, 2002, p. 65), ou ainda ao mudar-se para o norte do Roraima, onde caíram os galhos da árvore Wazaká, permitindo o florescimento de uma maior quantidade de alimentos (KOCH-GRÜNBERG, 2002, p. 65).

Por fim, vale dizer que o herói pemon, assim como muitos outros tricksters, possui uma relação particular com a linguagem. O verbo tem um poder de alteração da realidade, como acontece com alguns deuses e demiurgos. Com isso, a linguagem liberta-se do plano meramente abstrato e, graças ao trickster, atinge o plano concreto (um furo no tecido de possibilidades), torna-se coisa, fato. Assim, basta Makunaima ordenar a uma planta "Transforma-te numa arraia e vai para junto de Jigué! Quando 
ele pisar em cima de ti, pica-lo" (KOCH-GRÜNBERG, 2002, p. 71) que o evento ocorre. Há outros exemplos. Num deles o herói estava preso em um cesto e "ficou pensando: 'Como é que vou sair do cesto?' Disse ao cesto: 'Abre tua boca, tua grande boca!' Então o cesto abriu a boca" (KOCHGRÜNBERG, 2002, p. 73). Dentre todas as opções, o uso do verbo como elemento mágico, capaz de alterar a realidade, foi a escolhida, o que demonstra talvez uma superioridade da linguagem até sobre qualquer plano astucioso, visto que nada pode ser mais simples do que apenas falar e, com isso, dar à realidade o contorno que se deseja. A própria derrubada de Wazaká teve que contar com o apoio da linguagem:

Makunaíma começou a dar golpes num lado do tronco, Jigué no outro, Jigué golpeava e dizia: 'Wainayég ' ${ }^{\cdot 107}$. Então um dos lados do tronco foi ficando cada vez mais duro.

Makunaíma, porém, golpeava mais depressa que Jigué e dizia sempre: 'Elupa-yég, makúpa-yég ' ${ }^{108}$. Então este lado foi ficando cada vez mais mole. A árvore quebrou-se $(\mathrm{KOCH}$ GRÜNBERG, 2002, p. 61).

Esse poder da linguagem dialoga com o poder mutante do trickster. Makunaima, como vimos em vários mitos aqui destacados, transmuta coisas, pessoas, objetos e a si próprio. Parece-nos, contudo, que as mutações provocadas por Makunaima alteram ontologicamente os objetos de suas mutações, já que as pessoas transformadas em pedra até hoje estão no Monte Roraima em forma de rochas, dando a impressão de terem perdido sua natureza de pessoa. As mutações sobre si próprio, todavia, não alteram sua natureza e Makunaima mantém sua consciência identitária, tanto que normalmente retorna à sua forma original.

Makunaima chega a ser capaz, inclusive, de determinar acontecimentos futuros e romper a lógica pelo uso da linguagem. Ele retira feridas do seu corpo, as arremessa sobre o chão, as transforma em pedras e diz: “'Ficai aqui! Pegai em toda gente que passar por aqui!' Por isso aqueles que usam esse caminho hoje, ficam com feridas" (KOCH-GRÜNBERG, 2002, p. 61). A par do maravilhoso, a lógica é rompida pela própria ideia

\footnotetext{
${ }^{107}$ Explica, o autor, em nota de rodapé: "Nome duma árvore de madeira muito dura; aqui significa uma espécie de fórmula mágica" (KOCH-GRÜNBERG, 2002, p. 61).

${ }^{108}$ Explicita, o etnógrafo, em nota de rodapé: "Bananeiras. O tronco da bananeira é tão mole que pode ser abatido de um só golpe. Aqui os nomes deverão exercer uma influência mágica sobre o tronco da árvore Wazaká" (KOCH-GRÜNBERG, 2002, p. 61).
} 
de as pedras cumprirem a ordem de "pegar em toda gente que passar por aqui”, já que se trata de um objeto inanimado, incapaz de qualquer ato para fazer alguém ser por ele machucado.

As observações anteriores nos levam a concluir que Makunaima apresenta todas as características deste tópico, bem como as dos anteriores, sendo, portanto, um típico trickster.

\section{CONCLUSÃO}

Pelo exposto, conclui-se que ambos os personagens são tricksters. Mário de Andrade certamente percebeu que havia um certo grupo de personagens com características comuns, embora, ao tempo em que escreveu o livro, o conceito de trickster ainda não estivesse traçado pela antropologia. Não à toa, além de dar ao seu protagonista o nome de um importante trickster sul-americano, informa, no capitulo "Macumba", que Macunaíma é filho de Exu, outro clássico trickster.

Contudo, o "herói de nossa gente" não conseguiu completar seu ciclo, não livrou-se do domínio do princípio do prazer, por isso, ao contrário do seu coirmão mitológico, acaba derrotado, sem conseguir adaptar-se ao mundo.

\section{REFERÊNCIAS}

ANDRADE, Mário de. Cartas a Manuel Bandeira. São Paulo: Ediouro, s/d. . Macunaima: o herói sem nenhum caráter. Belo Horizonte: Villa Rica Editoras Reunidas, 2007.

CAMPOS, Haroldo de. Morfologia do Macunaima. São Paulo: Perspectiva, $\mathrm{s} / \mathrm{d}$.

CÂNDIDO, Antônio. Dialética da Malandragem. Disponível em: <http://www.unioeste.br/prppg/mestrados/letras/leitura/DIALETICA_ MALANDRAGEM.rtf $>$. Acesso em: 27/11/2013.

CARVALHO, Silvia M.S de. O trickster como personificação de uma práxis. In: Perspectivas, v. 8, p. 177-187. São Paulo: 1985. 
1997.

. Macunaíma, Maíra e Quarup. In: Itinerários, p. 55-80. Araraquara,

CARVAlHO, Fábio Almeida de; JOBIM, José Luis. Makunaima/Macunaíma: os caminhos de um personagem transnacional. In: JOBIM, José Luis. Literatura e cultura: do nacional ao transnacional. Rio de Janeiro: EDUERJ, 2013.

ELIADE, Mircea. Mito do Eterno Retorno. São Paulo: Mercuryo, 1992.

FREUD, Sigmund. Além do princípio do prazer. Disponível em: <http://lacan.orgfree.com/freud/textosf/alemdoprincipiodeprazer.pdf〉. Acesso em: 11/08/2015.

HYDE, Lewis. Trickster Makes This World: Mischief, Myth, and Art. Epub. Nova York: Farrar, Straus and Giroux, 1998.

JUNG, Carl Gustav. A psicologia da figura do trickster. In: Obras Completas de C.G. Jung, vol. 9: os arquétipos e o inconsciente coletivo. 2a ed. Petrópolis: Vozes, 2000.

KOCH-GRÜNBERG, T. Mitos e lendas dos índios Taulipáng e Arekuna. In: MEDEIROS, Sérgio. Makunaima e Jurupari: cosmogonias ameríndias. São Paulo: Perspectiva, 2002.

LÉVI-STRAUSS, Claude. Antropologia Estrutural. 1ª ed. São Paulo: Cosac Naify, 2012.

Mito e significado. Disponível em: <http://charlezine.com.br/wpcontent/uploads/Mito-e-Significado-L\%C3\%A9vi-Strauss.pdf $>$ Acesso em: 27/11/2013.

MEDEIROS, Sérgio. Makunaíma e Jurupari: cosmogonias ameríndias. São Paulo: Perspectiva, 2002.

PROENÇA, Manoel Cavalcanti. Roteiro de Macunaima. 5a ed. Rio de Janeiro: Civilização Brasileira, 1978. 
RADIN, Paul. The Trickster: A Study in American Indian Mythology. New York: Philosophical Library, 1956.

SOUZA, Eneida Maria de. A pedra mágica do discurso. $2^{\text {a }}$ ed. Belo Horizonte: Ed. UFMG, 1999.

SOUZA, Gilda de Mello e. O tupi e o alaúde. 2a ed. São Paulo: Editora 34, 2003.

SUBIRATS, Eduardo. "Macunaíma: brincar, reír, mudar". In: . Mito y literatura. México: Siglo XXI Editores, 2014.

VIVEIROS DE CASTRO, Eduardo. A inconstância da alma selvagem e outros ensaios de antropologia. São Paulo: Cosac Naify, 2002.

Recebido em: 14/06/2016

Aceito em: 15/07/2016 